\title{
A (TRANS)FORMAÇÃO DO ETHOS FEMININO NO DISCURSO PUBLICITÁRIO: o caso da marca Volkswagen
}

\author{
Cândice Quincoses ${ }^{1}$ \\ Ronivaldo Moreira de Souza ${ }^{2}$ \\ Deise Balek ${ }^{3}$
}

\begin{abstract}
Resumo: O trabalho investiga o ethos feminino no discurso publicitário verificando suas influencias na construção de tendências e comportamentos da sociedade. Tendo em mente que o discurso publicitário se apropria de toda a conjuntura sociopolítica e cultural para construir seus argumentos, esta pesquisa primeiramente toma como base as reflexões de Beauvoir, Bourdieu e Moscovici, para compreensão das distinções de gênero e do papel social da mulher. Em seguida, retoma as noções de ethos e estereótipos da Análise do Discurso da Escola Francesa para verificar como estas noções que habitam o imaginário social se materializam no discurso publicitário. O corpus da pesquisa é composto por três campanhas da Volkswagen duas durante a ditadura e outra veiculada no Dia Internacional da Mulher em 2010. A análise constatou que mesmo havendo uma mudança do discurso na propaganda mais recente, a figura masculina ainda é colocada como referência e a (trans)formação do ethos feminino acontece através de novas formações discursivas, ideológicas e novos estereótipos atribuídos a ela.
\end{abstract}

Palavras-chaves: Mulher, gênero, ethos feminino, estereótipo, discurso publicitário.

\begin{abstract}
The work investigates the feminine ethos in the advertising discourse verifying its influences in the construction of tendencies and behaviors of the society. Bearing in mind that the advertising discourse appropriates the entire sociopolitical and cultural conjuncture to construct its arguments, this research first takes as a basis the reflections of Scott, Beauvoir, Bourdieu and Moscovici, to understand the distinctions of gender and the social role of women. Then retakes the notions of ethos and stereotypes of the Discourse Analysis of the French School to verify how these notions that inhabit the social imaginary materialize in the advertising discourse. The research corpus consists of three campaigns of Volkswagen-two during the dictatorship and another on International Women's Day in 2010. The analysis found that even though there is a shift in discourse in recent advertising, the male figure is still referred to as a reference and the (trans) formation of the feminine ethos takes place through new discursive, ideological formations and new stereotypes attributed to it.
\end{abstract}

Keywords: Woman, gender, feminine ethos, stereotype and advertising speech.

\section{Introdução}

$\mathrm{O}$ artigo tem como finalidade investigar o ethos feminino no discurso publicitário, através dos enunciados discursivos e as representações femininas e sociais, bem como a forma

\footnotetext{
${ }^{1}$ Mestre em Comunicação Social pela Metodista (UMESP). Especialista em Comunicação Estratégica pelo SENAC-RS. Professora da Graduação de Relações Públicas da Fundação Escola e Comércio Álvares PenteadoFECAP. Atua na área de Comunicação do Sicoob Cecres. Bacharel em Relações Públicas e Jornalismo pela Universidade Católica de Pelotas-UCPEL. E-mail: candi_sq@ @otmail.com.

${ }^{2}$ Mestre em Ciências das Religiões pela Faculdade Unida de Vitória. Doutorando em Comunicação Social UMESP. Membro do grupo de pesquisa COLING (Estudos de Comunicação e Linguagem). Bolsista Integral CAPES. E-mail: ronivaldomds@gmail.com.

${ }^{3}$ Mestre em Comunicação Social (UMESP-2016), Profa. no curso de Adm. de Empresas no CUFSA, Coord. Customer Care na DuPont do Brasil desde 2001. MBA em Capacitação Gerencial e Especialista em Marketing e Recursos Humanos pelo CUFSA.
} 
que tais representações se manifestaram em distintas épocas através do ethos que se consolida em alguns discursos publicitários.

No que diz respeito à condição feminina, serão apresentadas diferenças atribuídas entre os gêneros masculinos e femininos, sendo que ambos estão diretamente ligadas a uma construção social, ou seja, formas de dominação estabelecidas pela sociedade que cultivam diferenças entre os sexos, e que se baseiam em distinções puramente fisiológicas.

Já no que se refere ao discurso publicitário, é notório que se apropria de categorias socioculturais para materializar a construção discursiva da marca ou do produto/serviço que pretende vender. Para isto, utiliza estereótipos criando modelos ideais que facilitam o processo de identificação e projeção com o público-alvo. No entanto, estes estereótipos são formados por representações sociais do real e podem sofrer mudanças de acordo com o período no qual são retratados.

O corpus da pesquisa foi composto por três campanhas publicitárias da marca Volkswagen, sendo dois anúncios da década de 1960, período do regime militar, e um comercial de 2010 veiculado no Dia Internacional da Mulher. As campanhas retratam a construção do ethos feminino e utilizam estereótipos atribuídos à imagem da mulher para persuadir e atrair o consumidor que tem o poder de compra.

\section{O Gênero e a condição feminina}

$\mathrm{O}$ gênero tem sido empregado para fundamentar o assunto referente às diferenças sexuais, as representações e papéis sociais tradicionais que foram designados às mulheres e aos homens. Portanto, ao pesquisar o gênero percebe-se que a condição da mulher não está definida pela natureza do sexo, mas sim por uma construção social.

Segundo a pesquisadora francesa Simone de Beauvoir (1970, p. 13) que estuda gêneros e o sexo feminino:

Todo ser humano do sexo feminino não é, portanto, necessariamente mulher; cumpre-lhe participar dessa realidade misteriosa e ameaçada que é a feminilidade. Será esta secretada pelos ovários? Ou estará congelada no fundo de um céu platônico? E bastará uma saia ruge-ruge para fazê-la descer à rua? Embora certas mulheres se esforcem por encarná-lo, o modelo nunca foi registrado. 
A autora ressalta que o feminino não é algo imparcial, mas que abarca a figura social construída em torno da imagem do sexo feminino e que esse modelo vem sendo ameaçado devido às mudanças sociais. Neste sentido, é importante destacar as diferenças entre o sexo e o gênero, pois muitas vezes são tratados com igualdade, porém ambos apresentam significados distintos que representam a construção da sociedade humana.

Por mais que muitos o considerem a mesma coisa, o sexo e o gênero são distintos. O sexo corresponde às particularidades fisiológicas, referente à germinação humana ou ato de procriar. O sexo se divide entre: homens - que são dotados de gameta masculino que produzem o esperma - e de mulheres, que possuem o gameta feminino e produzem os óvulos

\footnotetext{
O sexo biológico, ou seja, as características anátomo-fisiológicas das pessoas vêm determinadas, em geral, pela dotação cromossômica, pelas estruturas gonodais e pela dotação hormonal (fetal, pós-natal e puberal) responsáveis da estruturação genital interna e externa dos caracteres sexuais secundários (desenvolvidos na puberdade). (STREY, 2013, p.181).
}

A autora salienta que o sexo no qual as pessoas nascem, tanto o feminino quanto o masculino, não diz respeito à sua orientação sexual, tampouco as práticas, estilos de vida, comportamentos, desejos, gostos, vontades, interesses e papéis desempenhados na sociedade, ou seja, as escolhas que serão feitas dependerão exclusivamente de cada um, das suas vontades, bagagens culturais e aspectos sociais. Com isso, compreende-se que o sexo é constituído pela diferença física, simbolizado por órgãos sexuais, ou seja, as pessoas nascem com um órgão que o diferencia do masculino para o feminino

Scott (1988) questiona igualdade e diferença do gênero, tendo em vista que uma não anula a outra. Dessa forma, as pessoas nascem iguais, porém são desiguais. Ela critica as diferenças entre o macho e fêmea e acredita que isso contribui para as distinções entre os homens e as mulheres na sexualidade, na forma de comportamento, de convivência, na assimilação de gênero, dentre outros.

O gênero "tornou-se uma palavra particularmente útil, pois oferece um meio de distinguir a prática sexual dos papéis sexuais atribuídos às mulheres e aos homens (Scott, 1995, p.75). Para a autora o gênero é algo que se estabelece das relações sociais. Portanto, entende-se que o gênero é basicamente uma construção social e histórica, e deve ser percebido com diferenças entre o feminino e masculino. Enquanto que o sexo na sua essência refere-se à identificação fisiológica do indivíduo, o gênero abarca a construção social.

Seguindo esta ideia, Bourdieu (2007, p.11) diz: 
a diferença biológica entre os sexos, isto é, entre o corpo masculino e o feminino, e, especificamente, a diferença anatômica entre os órgãos sexuais, pode assim ser vista como justificativa natural da diferença socialmente construída entre os gêneros e, principalmente, da divisão social do trabalho.

$\mathrm{O}$ autor menciona que as distinções biológicas, especialmente as que se referem à divisão do trabalho, de procriação e de reprodução, operam como uma ilusão coletiva mais bem fundamentada. Para ele, a sexualidade já coloca a mulher numa condição desfavorável. Cabe destacar que o propósito não é ser contrário as diferenças biológicas, porém apresentar que às vezes são argumentos usados para enaltecer as diferenças culturais.

Os estudos sobre os conceitos de gênero são importantes para a compreensão dos papéis sociais que ambos, homens e mulheres, representam em especial o da mulher, pois apresenta um entendimento sobre suas diferenças e suas disparidades conceituais. O gênero como construção cultural torna-se evidente "quando se verifica que ser homem ou mulher nem sempre supõe o mesmo em diferentes sociedades ou em diferentes épocas" (STREY, 2013, p.182).

Neste sentido, pode se dizer, que até pouco tempo, a mulher era percebida como um gênero inferior e submisso em distintos ambientes sociais, como na família, na Igreja, no Estado. O homem exercia o papel de chefe da família, sendo responsável pelas despesas financeiras.

À luz destas questões, Bourdieu (1999) reforçava este pensamento, afirmando que uma sociedade machista coloca a mulher num mesmo patamar de uma propriedade, que dá ao homem a sensação de poder e domínio sobre ela. Continua ainda dizendo que o homem aproveitava de seu corpo como objeto de prazer para provar sua virilidade podendo chegar ao ponto de considerá-la uma serviçal, que devia estar disponível para satisfazer suas necessidades, tanto nas relações sexuais quanto no cumprimento de tarefas domésticas. Para o autor, isso também influenciava nas divisões das atividades de trabalho, enquanto ao homem são estabelecidas atribuições de força, às mulheres qualidades de sensíveis e frágeis.

Deste modo, uma das características dos estudos de gênero é a verificação de que as divisões foram social e culturalmente construídas. Contudo, sabe-se que existe uma revisão do gênero e da condição da mulher na sociedade:

uma mulher que antes era criada para seguir a tradição familiar, cuidando dos filhos, da casa e do marido, prosseguia no eixo religioso de seus pais vivendo os dogmas da igreja inquestionavelmente. Agora, pela quebra da tradição e pela revisão dos papeis de gênero, uma vez repensados seus valores na sociedade, desenvolve 
uma nova cosmovisão que altera sua relação familiar, sua forma de criar os filhos, de cuidar da casa e do marido e, inexoravelmente, sua forma de ver a religião, agora não mais dogmática inquestionável, mas como doutrina passiva de questionamentos e, se assim desejar, até de rejeição. (SOUZA, 2013, p. 54).

A construção do gênero e da condição da mulher é histórica, social e cultural, e está em constante mutação, já que a mulher busca conquistar o seu espaço representativo na sociedade. Neste processo evolutivo, a mulher vem rompendo com os paradigmas sociais construídos.

\section{A Representação Social Feminina}

Ao tratar sobre este assunto é preciso buscar apoio nas suas origens que, segundo Moscovici (1994), surgiu no estudo da Sociologia e da Antropologia e foi nomeada primeiramente por Durkhein como uma representação coletiva, sendo meio essencial para a criação de uma teoria da religião e ideologias míticas. Moscovici menciona um conceito a respeito da representação social pela primeira vez na pesquisa: "Psychanalyse, sonimage et son publique", quando investiga de que forma a psicanálise ao sair de grupos fechados é ressignificada por grupos populares.

Em seus estudos das representações sociais Moscovici (1981, p. 181) não faz uma abordagem definitiva e objetiva do conceito, porém ele tenta encontrar uma fundamentação dizendo que:

é um conjunto de conceitos, proposições e explicações originado na vida cotidiana no curso de comunicações interpessoais. Elas são equivalentes, em nossa sociedade, aos mitos e sistemas de crenças das sociedades tradicionais: podem também ser vistas como a versão contemporânea do senso comum.

Com isso, entende-se que as representações sociais são percepções dos indivíduos, elaboradas e partilhadas coletivamente. É preciso entender que as representações não são respostas criadas na mente das pessoas por meio de estímulos do meio social, mas uma constituição do significado do meio social, em que ambos se constroem ao mesmo tempo, sendo um determinado pelo outro. Ela carrega um significado simbólico na mente das pessoas.

Já Guareschi (1996) salienta que são diversos os elementos que compõem a representação social como: aspectos culturais, cognitivos e valorativos e que cada um deles 
são impregnados nos sujeitos e objetos e por serem aspectos relacionais são sociais. A representação social pode ainda ser conceituada como "uma forma de conhecimento, socialmente elaborada e partilhada, tendo uma visão prática e concorrendo para a construção de uma realidade comum a um conjunto social" (JODELET, 1989, p. 36).

O conceito citado por Jodelet (1989) reforça a representação social estabelecida, interpretada e disseminada pela sociedade. Desta forma, pode-se dizer que baseia-se em uma cultura patriarcal, “[...] a autoridade social sobre as mulheres é exercida através dos papéis de pai e marido". (STREY, 2013, p.184). Essa percepção da mulher como inferior ao homem e objeto dele, resulta de valores tradicionais construídos que reiteram o papel da mulher de submissa na sociedade.

\section{Estereótipos na mídia}

Os estereótipos são rótulos criados, imagens preconcebidas sobre as coisas e as pessoas. São modelos criados (e repassados) de como deve ser o perfeito e o ideal na sociedade. É com base nestes estereótipos acerca dos papéis sociais da mulher, que moldamse as formas do preconceito existente na sociedade.

Os estereótipos são formados por imagens que constituem-se em elementos existentes em torno dos indivíduos, criando alguns pressupostos e generalizações a respeito de modelos padrões sociais. Os estereótipos são construídos como ideais e simulam aquilo que a sociedade deseja.

Seguindo esta visão, os estereótipos condicionam o comportamento das pessoas, influenciando na forma de falar, raciocinar, operar, vestir, provocando desejos e formando tendências. Os meios de comunicação utilizam os estereótipos em suas propagandas, nos filmes, novelas, documentários, anúncios, programas de entretenimento e outros; por que eles facilitam o processo de identificação e projeção entre enunciador e enunciatário, além de gerar necessidades coletivas. Conforme Bryan Key (1996), sempre existe uma finalidade previamente estabelecida na comunicação e tudo que abrange a maneira de compreender, interpretar, perceber os fatos, interfere nas relações sociais. Isso ocorre, na maioria das vezes, de forma inconsciente.

Com os estereótipos se moldam as formas do preconceito, por meio de personagens do dia a dia, tais como: a submissa, a dona de casa, a bem sucedida, a sarada, a frágil, a mulher 
entre outras. A imagem da mulher se transformou em um produto midiático explorado pela mídia.

Na cultura midiática, os estereótipos naturalizam aquilo que não é natural, ao se apropriar e criar as expectativas desejadas pelos indivíduos para construir e moldar a sociedade.

\section{O ethos no discurso publicitário: uma abordagem discursiva}

A noção de ethos foi introduzida nos estudos retóricos de Aristóteles (2005). As investigações do autor levaram-no a concluir que o orador ganha a confiança do auditório ao construir uma imagem de si que seja convincente. Essa boa impressão é causada pela maneira como o locutor constrói o discurso, isto é, desde as palavras que escolhe, argumentos, gestos e postura, até o tom de voz e modulação da fala. O ethos, objeto de estudo de Aristóteles, considerou especificamente a imagem que o locutor constrói de si no decorrer do discurso, ou seja, o ethos ligado ao próprio ato de enunciação. Ducrot retomou esse conceito ao trabalhar a ideia de que o ethos não é dito no enunciado, mas mostrado na enunciação:

\footnotetext{
É necessário entender por isso o caráter que o orador atribui a si mesmo pelo modo como exerce a sua atividade oratória. Não se trata de afirmações auto-elogiosas que ele pode fazer de sua própria pessoa no conteúdo de seu discurso, afirmações que podem ao contrário chocar o seu ouvinte, mas da aparência que lhe confere a fluência, a entonação, calorosa ou severa, a escolha das palavras, os argumentos (DUCROT, 1987. p.188-189).
}

A construção de uma imagem de si acontece mutuamente entre enunciador e seu receptor. Pêcheux (1997, p. 82) propôs essa perspectiva ao afirmar que "o que funciona nos processos discursivos é uma série de formações imaginárias que designam o lugar que A e B se atribuem cada um a si e ao outro, a imagem que eles se fazem de seu próprio lugar e do lugar do outro".

A proposta metodológica de Pêcheux aproxima a subjetividade da língua com a objetividade das práticas sociais tendo como ponto de encadeamento o discurso:

No discurso, as relações entre esses lugares, objetivamente definíveis, acham-se representadas por uma série de 'formações imaginárias' que designam o lugar que destinador e destinatário atribuem a si mesmo e ao outro, a imagem que eles fazem de seu próprio lugar e do lugar do outro. Dessa forma, em todo processo discursivo, o emissor pode antecipar as representações do receptor e, de acordo com essa 
antevisão do 'imaginário' do outro, fundar estratégias de discurso (BRANDÃO, 2004, p. 44).

Essa percepção fundamenta a noção de ethos como concebida pela Análise do Discurso de Escola Francesa: a posição do locutor como sujeito do discurso, construindo esse jogo de imagens no processo comunicativo.

Assim, o assunto se inscreve em duas vertentes: na primeira o ethos é fruto da enunciação, uma construção da imagem de si no ato da fala; no segundo, ele é fruto de uma interação entre os parceiros da comunicação podendo ser, inclusive, anterior à enunciação (MAINGUENEAU, 2008. p.63).Para simplificar, basta concluir que, no momento em que toma a palavra, o enunciador imagina seu auditório e a maneira pela qual esse auditório vai percebê-lo; "avalia o impacto sobre seu discurso atual e trabalha para confirmar sua imagem, para reelaborá-la ou transformá-la e produzir uma impressão conforme as exigências de seu projeto argumentativo" (AMOSSY, 2005. p.125).

\section{Ethos e estereótipos no discurso publicitário}

Para construir sua noção de ethos e aplicá-la às cenas da enunciação, Maingueneau se apropriou de três pressupostos da retórica de Aristóteles, admitindo o ethos como: 1) uma noção discursiva que se constitui por meio do discurso; 2) um processo interativo de influência sobre o outro; 3) "uma noção fundamentalmente hibrida (sociodiscursiva), um comportamento socialmente avaliado, que não pode ser apreendido fora de uma situação de comunicação precisa, ela própria integrada a uma conjuntura sócio-histórica determinada"(MAINGUENEAU, 2008. p.63).

A maneira como a publicidade se dirige ao público é um indício da imagem que faz dele, parte fundamental para o sucesso na execução do contrato estabelecido e elemento básico na identificação das condições de produção:

\footnotetext{
O discurso publicitário contemporâneo mantém, por natureza, um laço privilegiado com o ethos; de fato, ele procura persuadir associando os produtos que promove a um corpo em movimento, a uma maneira de habitar o mundo; como o discurso religioso, em particular, é por meio de sua própria enunciação que uma propaganda, apoiando-se em estereótipos avaliados, deve encarnar o que ela prescreve (MAINGUENEAU, 2008, p. 66).
}

Essas categorias socioculturais das quais o discurso publicitário se apropria para inscrever seus enunciatários, são materializadas na construção discursiva da marca ou do 
produto/serviço que será vendido. Por tratar-se de representações sociais do real, estes estereótipos podem sofrer constantes (trans)formações de acordo com as construções sociais de uma dada categoria em uma determinada época. Esse processo de estereotipagem pode ser definido como

\begin{abstract}
a operação que consiste em pensar o real por meio de uma representação cultural preexistente, um esquema coletivo cristalizado [...]. O locutor só pode representar seus locutores se os relacionar a uma categoria social, étnica, política ou outra [...]. O orador adapta sua apresentação de si aos esquemas coletivos que ele crê interiorizados e valorizados por seu público-alvo (AMOSSY, 2005. p.125-126).
\end{abstract}

Constata-se, portanto, que o discurso publicitário cria um enunciatário ideal baseado nessas representações sociais e, a partir disso, dirige a sua linguagem e argumentos persuasivos à este público. A construção imaginária da marca ou do produto/serviço, se apoiará nesses estereótipos, e a marca constrói seu ethos atribuindo uma imagem correlata ao enunciatário que se destina.

\title{
7. O caso da Volkswagen
}

Esta pesquisa selecionou três anúncios publicitários da marca Volkswagen em períodos distintos para analisar como a marca se apropriou do estereótipo feminino para elaboração de seu discurso de venda. Os dois primeiros anúncios são da década de 1960 e utilizam a linguagem visual e textual. Já o terceiro foi uma campanha da marca veiculada no dia internacional da mulher em 2010.

\subsection{O estereótipo feminino na campanha pela compra do segundo carro}

Os dois primeiros anúncios analisados tinham como objetivo introduzir uma cultura no mercado brasileiro: criar a necessidade da compra de um segundo veículo para atender às demandas da família. Em ambos os casos, a marca se apoia claramente no estereótipo feminino e direciona seu discurso ao homem, a quem atribui a competência do poder de compra.

No caso do primeiro anúncio, a marca colocou a imagem de um Fusca com o paralama amassado. Logo abaixo, em negrito, aparece o enunciado: "Mais cedo ou mais tarde a sua esposa vai dirigir. Esta é uma das razões para você ter um Volkswagen". 


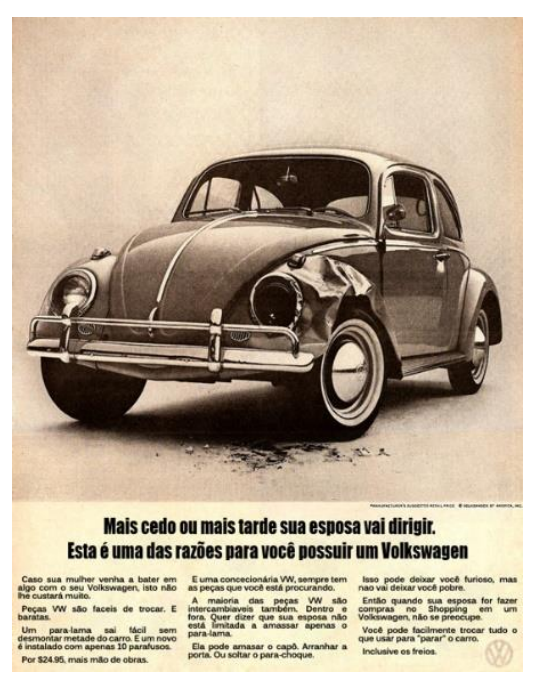

Segue-se a este enunciado alguns argumentos que reforçam, por um lado a durabilidade das peças e o baixo custo de reposição, e por outro, um discurso que se apoia no dito popular: "mulher no volante é perigo constante":

"Caso a sua mulher venha a bater em algo com o seu Volkswagen, isto não lhe custará muito. Peças VW são fáceis de encontrar e baratas. Um para-lama sai fácil sem desmontar metade do carro. E um novo é instalado com apenas 10 parafusos. Por $\$ 24.95$, mais mão de obras. $E$ uma concessionária $V W$ sempre tem as peças que você está procurando. A maioria das peças $V W$ são intercambiáveis também. Dentro e fora. Quer dizer que sua esposa não está limitada a amassar apenas o para-lama. Ela pode amassar o capô. Arranhar a porta. Ou soltar o para-choque. Isso pode deixar você furioso, mas não vai deixar você mais pobre. Então quando sua esposa for fazer compras no shopping em um Volkswagen, não se preocupe. Você pode trocar tudo o que usar para "parar" o carro. Inclusive os freios".

No segundo anuncio analisado, a marca utiliza a imagem de um Fusca. Ao lado dele,

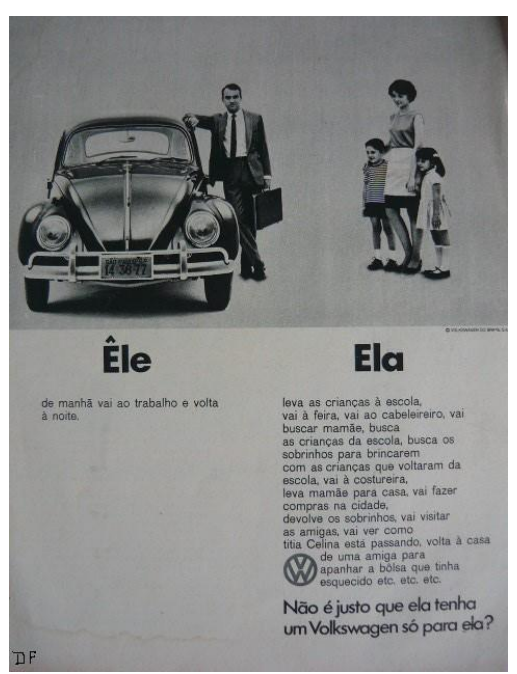
se apoiando sobre o teto, está um homem vestido de terno e gravata representando o estereótipo de um executivo. Do lado esquerdo da imagem, aparece uma mulher, vestida com um avental, com duas crianças ao lado. Os enunciados que se seguem são os seguintes:

"Ele: de manhã vai ao trabalho e volta à noite.

Ela: leva as crianças à escola, vai à feira, vai ao cabelereiro, vai buscar mamãe, busca as crianças da escola, busca os sobrinhos para brincarem com as crianças que voltaram da escola, vai à costureira, leva mamãe para casa, vai fazer compras na cidade, devolve os sobrinhos, vai visitar as amigas, vai ver como titia Celina está passando, volta à casa de uma amiga para apanhar a bolsa que tinha esquecido etc., etc., etc. Não é justo que ela tenha um Volkswagen só para ela?"

\subsection{Análise discursiva das peças}

Em ambos os casos percebe-se uma clara harmonia do plano de expressão com o plano de conteúdo. O plano de conteúdo integra-se ao plano de expressão e toma parte nele. 
No primeiro caso analisado, percebe-se que o uso da pontuação transcende as exigências da norma culta, e as vírgulas são substituídas por pontos finais. Essa estratégia dá ao texto uma constante quebra na cadência e no ritmo, provocando no leitor constantes interrupções e retomadas. Esse efeito provocado na leitura, lembra a forma inconstante de uma pessoa não acostumada com o volante, que oscila entre acelerações e frenagens demasiadas.

Já no segundo anúncio, temos o percurso inverso: a saturação de vírgulas onde poderia haver pontos finais. A proposta do anúncio é contrastar rotinas. Enquanto a rotina do homem é descrita em uma única frase, sem uso de vírgulas entre períodos, a rotina da mulher usa o recurso gráfico em demasia. A leitura do texto seguindo esta proposta de pontuação faz com que o leitor chegue ao final de forma ofegante. É a soma de intermináveis afazeres dispostos nessa sequencia textual que preparam o leitor para responder positivamente à pergunta final com um sono "SIM".

\section{O estereótipo da dona de casa}

Os dois anúncios apresentam uma clara distinção entre o homem e a mulher. Esta divisão se materializa em divisões de trabalho. Tendo em vista que esta imagem que a marca constrói do universo feminino se apoia em uma conjuntura sociocultural, faz-se necessário recorrer ao período histórico em que esses anúncios foram veiculados.

O Brasil atravessava o período da ditadura militar. Diante da repressão, alguns movimentos feministas surgiram - mesmo que inicialmente de forma bastante inibida - como oposição às condições impostas pelo governo e por uma sociedade patriarcal, tentando romper com as representações tradicionais da mulher de que o lugar dela é em casa cuidando do marido e da família. Claro que o momento sócio-histórico do Brasil - a ditadura militar exacerbava a visão do papel da mulher como restrito exclusivamente ao lar, no entanto, não podemos negar que há um plano de fundo cultural tanto na cultura brasileira quanto na latinoamericana, de um modo geral, que validava esse discurso restringindo a mulher a esse lugar social de fala. A mulher que fugia desse estereótipo era facilmente encarada como uma anomalia

De imediato constato que a mulher, militante política é encarada como um ser "desviante", não uma mulher normal e desejável. Esta estava no espaço a ela destinado, no santuário do lar, cuidando do marido e dos filhos. A mulher militante política nos partidos de oposição à ditadura militar cometia dois pecados aos olhos 
da repressão: de se insurgir contra a política golpista, fazendo-lhe oposição e de desconsiderar o lugar destinado à mulher, rompendo os padrões estabelecidos para os dois sexos. A repressão caracteriza a mulher militante como Puta Comunista. Ambas categorias desviantes dos padrões estabelecidos pela sociedade, que enclausura a mulher no mundo privado e doméstico (COLLINGS, 1997, p.7).

Observa-se claramente nos anúncios como essa distinção conflituosa do espaço social se cristaliza no discurso da marca Volkswagen. No caso do primeiro anúncio, o argumento se baseia na inabilidade da mulher em dirigir com a mesma perícia do homem. O texto é claramente dirigido ao homem, todos os pronomes possessivos atribuem a ele o poder da posse, tanto sobre a mulher quanto sobre o automóvel que, apesar de ser dirigido pela mulher, continua sendo dele: "Caso a sua mulher venha a bater em algo com o seu Volkswagen, isto não lhe custará muito ( grifo nosso)".

Enquanto o homem assume seu lugar social de trabalhador, provedor e, por isso só, superior à mulher, à ela é dado o lugar correlato do ócio e da vida fútil e inferior: "Então quando sua esposa for fazer compras no shopping em um Volkswagen, não se preocupe. Você pode trocar tudo o que usar para 'parar' o carro. Inclusive os freios".

Já no segundo anuncio, essa distinção é explícita tanto no texto quanto na imagem. O homem vestido com trajes executivos aponta para o universo masculino, enquanto a mulher de avental ao lado das duas crianças define seu lugar social: cuidar das responsabilidades domésticas e educar os filhos.

No texto, a superioridade do homem e sua atividade são mostradas no seguinte enunciado: “ele: de manhã vai ao trabalho e volta à noite". A sequência fastidiosa de atividades da rotina feminina em momento algum é chamada de trabalho. A economia no enunciado que define o universo masculino, parece auto justificar-se na expressão: trabalho. Não é preciso acrescentar nada, nem descrever sua atividade. Já no universo feminino a multiplicidade de atividades alterna-se entre deveres domésticos e a ociosidade fútil. Nada na rotina feminina justifica sua importância, ao contrário disso, só enaltece sua necessidade de ter um automóvel para facilitar o prolongamento de sua rotina.

A marca constrói seu discurso situando o homem e a mulher em lugares sociais distintos. O discurso não apenas assume essa diferença, mas também, a acentua. O produto Fusca surge como um produto que atende às necessidades do universo masculino e sua superioridade social, e que também atende as necessidades do universo feminino e suas inabilidades e inferioridade. A distinção entre os dois universos se encontra em um produto comum: o Fusca. Desta forma, parece honroso para a mulher dirigir um carro que pertence a 
um universo superior ao seu, e parece digno ao homem dar à sua esposa um produto tão “superior" para que ela realize atividades tão inferiores. Vale lembrar que o anúncio analisado aqui é de um período histórico específico e destinado a um enunciatário de uma classe social específica: a classe média brasileira. É isso que possibilita o domínio dos códigos mediando a relação enunciador/enunciatário. No entanto, com as transformações sociais em curso na contemporaneidade surge um paradoxo: a mulher não perde de todo o seu papel social de cuidadora do lar, porém, se moderniza à medida em que alcança certa autonomia para "mover-se" por si própria.

\section{Rupturas e continuidades no estereótipo feminino}

O próximo comercial analisado foi veiculado pela marca no Dia Internacional da Mulher em 2010, no formato audiovisual. Segue abaixo a transcrição do texto enunciado por um narrador:

"No dia internacional da mulher, um comercial para ajudar os homens. Você pode dar um carro zero para a sua mulher, mas não se assuste se ela gostar mais da cartinha que você escondeu no porta-luvas. Dirigir bem não é sinal de virilidade. Uma mulher prefere um barbeiro que percebe que ela está usando um vestido novo, do que um super piloto incapaz de notar que ela mudou o corte de cabelo. Elas não gostam daquela buzinadinha de aprovação. Mesmo que gaste uma fortuna na academia, a mulher prefere elogios sobre sua personalidade do que sobre seu corpo. Carro bonito não é garantia de sucesso. E no primeiro encontro as mulheres nem lembram do modelo do seu carro, mas não esquecem que você abriu a porta pra elas. E se você admitir que uma mulher dirige melhor do que você, acredite, o mundo não acaba. Uma homenagem da Volkswagen à sofisticada engenharia feminina",4.

O enunciado introdutório certifica que o destinatário deste comercial são os homens: "No dia internacional da mulher, um comercial para ajudar os homens". Porém, a natureza persuasiva desde discurso consiste em construir o ethos de uma marca que entende do universo feminino. É como se a marca imersa no universo feminino fosse desvendar aos homens os segredos e mistérios da "sofisticada engenharia feminina". A marca encerra seu discurso enunciando que sua homenagem às mulheres consiste em ensinar aos homens como bem trata-las.

4YouTube. Acesso em Out. 2015. Disponível em: 〈https://www.youtube.com/watch?t=61\&v=ZwTknzVvJCw〉. 
Porém, entre o enunciado introdutório e o conclusivo está uma construção estereotipada do universo feminino. Fato curioso é que o texto imagético que cobre a narrativa é uma mescla de ficção e realidade, imagens de desenhos animados, filmes, e imagens aparentemente extraídas do cotidiano; também observa-se a constante transição de imagens em preto e branco com imagens coloridas, imagens de uma época remota que são sucedidas por imagens atuais. Essas alternações entre o fictício e o real, o passado e o presente, provocam um efeito de verdade no discurso, pois, certifica ao enunciatário que esse comercial resulta de uma investigação de longas datas sobre o universo feminino e suas particularidades, observando o comportamento das mulheres em épocas diferentes, e em "mundos" diferentes. Esse jogo estratégico procura persuadir o enunciatário de que as constatações da marca sobre o universo feminino não resultam de achismos, mas, de observação cuidadosa e demorada.

O comercial apresenta a mulher como um ser complexo e difícil de entender. A todo momento opõe a razão masculina à emoção feminina. Intercala as atitudes que supostamente as mulheres aprovam, com aquelas que elas reprovam. É uma espécie de manual para os homens, sobre como agradar as mulheres. Diferente dos dois anúncios analisados anteriormente, este comercial acentua as diferenças do universo feminino e do masculino, porém, em um nível mais profundo, para além da divisão de trabalho. Esta distinção do homem e da mulher se baseia no campo das emoções e dos sentimentos.

Percebe-se que a marca se apropria de outros discursos sobre as mulheres, para ressignifica-los. A estrutura narrativa do comercial consiste em retificar (pré)conceitos que supostamente os homens tem em relação às mulheres. Cada parágrafo inicia-se baseando em crenças populares sobre o universo feminino: para os que acreditam que as mulheres não resistem a presentes caros, a marca afirma que elas preferem a carta deixada no porta-luvas; para aqueles que acreditam que as mulheres se encantam pelas habilidades masculinas ao volante, a marca alerta que elas preferem ser notadas; para aqueles que acreditam que as mulheres não resistem ao som da buzina de um veículo, a marca rechaça dizendo que elas preferem elogios sobre sua personalidade; para aqueles que creem que os homens que andam em carros bonitos tem mais sucesso com as mulheres, a marca orienta que elas preferem pequenos gestos de gentileza como abrir a porta do carro, por exemplo; por fim, para aqueles que acreditam que os homens são mais habilidosos que as mulheres ao volante, a marca afirma que admitir a habilidade feminina ao dirigir não é o fim do mundo. 
O comercial constrói seus argumentos baseando-se na imagem da mulher que deseja ser cortejada pelo homem, que preocupa-se com a sua aparência e que o faz para que o homem a note, e que se sente atraída muito mais pelas ações afetivas e sensíveis do homem, do que pelas suas demonstrações de habilidades viris. O homem provedor é substituído pelo homem cortês e cavalheiro, enquanto a doméstica e educadora dos filhos é substituída pela donzela complexa e sensível que aguarda ser conquistada.

\section{Considerações finais}

Ao final deste artigo, foi possível constatar como a marca Volkswagen constrói seu discurso publicitário, tendo em mente as diferentes posições sociais atribuídas à mulher, validando seu dizer por meio de estereótipos socialmente aceitos.

Nos três anúncios analisados, constata-se que o sucesso do discurso publicitário da marca em conquistar a adesão do enunciatário depende da observação do contexto sóciohistórico de sua enunciação. As mudanças na construção do ethos feminino na comparação dos anúncios almejam algo em comum, que é a busca pela aceitação de um determinado produto/serviço cujo principal consumidor é o homem.

Nos dois primeiros comerciais é o homem que tem o poder de compra, já no último, mesmo sendo mais contemporâneo, "constrói-se" uma mulher que anseia pela atenção do homem, atribuindo a ela um novo estereótipo, o de mulher romântica, sensível e frágil. Sendo assim, a marca utiliza diversas estratégias de persuasão e identificação do homem com o produto.

Com isso, percebe-se que a marca constrói seu discurso situando o homem e a mulher em lugares sociais distintos e os discursos apresentados nas propagandas reforçam essa diferenciação e (trans)formação do ethos feminino. 


\section{Referências}

AMOSSY, Ruth. Imagens de si no discurso: a construção do ethos. São Paulo: Contexto,2005.

ARISTÓTELES. Retórica. Lisboa: Imprensa Nacional-Casa da Moeda, 2005.

BEAUVOIR, Simone de. O segundo sexo fatos e mitos. Tradução de Sérgio Milliet. 4 ed. São Paulo: Difusão Europeia do Livro, 1970.

BOURDIEU, Pierre. A Dominação masculina. Tradução Maria Helena Kühner. 5. Ed. Rio de Janeiro: Bertrand Brasil, 2007.

BRANDÃO, Helena Hathsue Nagamine. Introdução à análise do discurso. Campinas-SP: Editora da Unicamp, 2004.

CAPRA, Fritjof. Sabedoria incomum. São Paulo: Cultrix, 1995.

COLLING, Ana Maria. A resistência da mulher à Ditadura Militar no Brasil. Rio de Janeiro: Rosa dos Tempos, 1997.

COLLING, Ana Maria. As Mulheres e a Ditadura Militar no Brasil, [s.1.],[s.a.] $<$ http://ich.ufpel.edu.br/ndh/downloads/historia_em_revista_10_ana_colling.pdf $>$. Acesso: em 25 de ago de 2014.

DUCROT, Oswald. O dizer e o dito. Campinas-SP: Pontes, 1987.

JODELET, D. Representations sociales: um domaineem expansion. In: ID (ed) Les representations sociales. Paris: Press Universitaires de France, 1989.

MAINGUENEAU, Dominique. Cenas da enunciação. São Paulo: Parábola Editorial, 2008.

MAINGUENEAU, Dominique. Novas tendências em análise do discurso. Campinas - SP: Pontes/Editora da Universidade Estadual de Campinas, 1997.

PATEMAN, Carole, Críticas feministas a la dicotomia publico/privado. In. CASTELLES, Carme (org). Perspectivas feministas en teoria política. Barcelona: Paidós, 1996.

PÊCHEUX, Michel. Análise automática do discurso. In: GADET, Françoise; HAK, Tony (Orgs). Por uma análise automática do discurso: Uma introdução a obra de Michel Pêcheux. $3^{\circ}$ Ed. Campinas-SP: Editora da Unicamp, 1997.

Scott, J. Gender and the politics of history. New York: Columbia University Press, 1988.

Scott, J. Gênero: uma categoria útil de análise histórica. Educação \& Realidade, 1995, 20, p. 71-99. 
STREY, Marlene Neves. Gênero. In: JACQUES, Maria da Graça Corrêa et al. Psicologia Social Contemporânea. Petrópolis/RJ: Vozes, 2013. P. 180-197. 